\title{
The emerging role of PET imaging in dementia [version 1; peer
}

\section{review: 3 approved]}

\author{
Leonardo Iaccarino ${ }^{1,2}$, Arianna Sala1,2, Silvia Paola Caminiti1,2, Daniela Perani (D)1-3 \\ ${ }^{1}$ Vita-Salute San Raffaele University, Milan, Italy \\ ${ }^{2}$ In Vivo Human Molecular and Structural Neuroimaging Unit, Division of Neuroscience, IRCCS San Raffaele Scientific Institute, \\ Milan, Italy \\ ${ }^{3}$ Nuclear Medicine Unit, IRCCS San Raffaele Hospital, Milan, Italy
}

V1 First published: 12 Oct 2017, 6(F1000 Faculty Rev):1830
https://doi.org/10.12688/f1000research.11603.1

Latest published: 12 Oct 2017, 6(F1000 Faculty Rev):1830

https://doi.org/10.12688/f1000research.11603.1

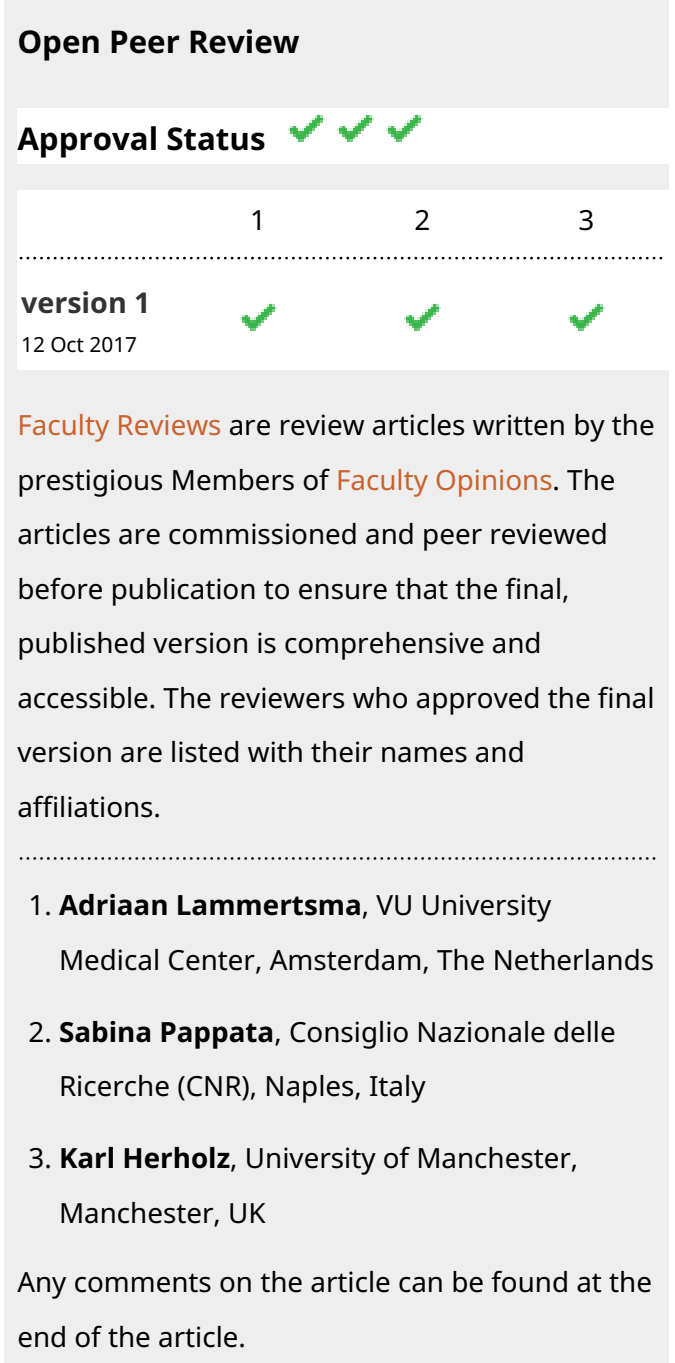

\begin{abstract}
A compelling need in the field of neurodegenerative diseases is the development and validation of biomarkers for early identification and differential diagnosis. The availability of positron emission tomography (PET) neuroimaging tools for the assessment of molecular biology and neuropathology has opened new venues in the diagnostic design and the conduction of new clinical trials. PET techniques, allowing the in vivo assessment of brain function and pathology changes, are increasingly showing great potential in supporting clinical diagnosis also in the early and even preclinical phases of dementia. This review will summarize the most recent evidence on fluorine-18 fluorodeoxyglucose-, amyloid -, tau -, and neuroinflammation - PET tools, highlighting strengths and limitations and possible new perspectives in research and clinical applications. Appropriate use of PET tools is crucial for a prompt diagnosis and target evaluation of new developed drugs aimed at slowing or preventing dementia.
\end{abstract}

\section{Keywords}

fluorodeoxyglucose, amyloid, tau, neuroinflammation , molecular imaging, diagnosis, prognosis, biomarker, dementia, PET

\section{3}


Corresponding author: Daniela Perani (perani.daniela@hsr.it)

Competing interests: The authors declare that they have no competing interests.

Grant information: The author(s) declared that no grants were involved in supporting this work.

Copyright: $\odot 2017$ Iaccarino L et al. This is an open access article distributed under the terms of the Creative Commons Attribution License, which permits unrestricted use, distribution, and reproduction in any medium, provided the original work is properly cited.

How to cite this article: Iaccarino L, Sala A, Caminiti SP and Perani D. The emerging role of PET imaging in dementia [version 1; peer review: 3 approved] F1000Research 2017, 6(F1000 Faculty Rev):1830 https://doi.org/10.12688/f1000research.11603.1

First published: 12 Oct 2017, 6(F1000 Faculty Rev):1830 https://doi.org/10.12688/f1000research.11603.1 


\section{Introduction}

The last decades have progressively witnessed a shift from a solely clinical diagnosis to a biomarker-supported diagnosis, and molecular neuroimaging techniques such as positron emission tomography (PET) have played a leading role in the dementia diagnostic work-up ${ }^{1-8}$. PET techniques have provided major advances, promoting novel approaches to support an early and differential dementia diagnosis. An accurate quantification, together with ad hoc PET techniques, can nowadays detect very subtle, but significant, pathological and functional neuronal changes, even before clinical symptoms arise. This is crucial for early interventions, personalized care planning, and inclusion in clinical trials ${ }^{9}$. Of note, several studies have demonstrated that PET techniques fully show their diagnostic and prognostic value especially when appropriate quantification methods are applied $^{10-13}$. These cardinal issues include timing and protocol of acquisition, parametric modelling and estimation, and the critical definition of the reference region to be used for semiquantification.

Here, we review the most recent advances, strengths, and weaknesses of four of the leading or novel PET tools (or both) in the dementia research field, namely ${ }^{18} \mathrm{~F}-\mathrm{FDG}$ (fluorine-18 fluorodeoxyglucose), amyloid, tau, and neuroinflammation PET imaging. The progressive implementation of these techniques, together with the standardization of appropriate methodologies, will allow unique breakthroughs in our understanding of neurodegeneration and will have remarkable implications for diagnostic algorithms and therapy monitoring.

\section{${ }^{18}$ F-fluorodeoxyglucose PET}

The fundamentals of ${ }^{18} \mathrm{~F}-\mathrm{FDG}$ PET are well established and are based on extensively explored molecular mechanisms? ${ }^{18} \mathrm{~F}-\mathrm{FDG}$ PET signal reflects astrocyte/neuron coupled energy consumption $^{14-17}$, and pioneering and recent studies support the notion that astrocytes play a central role in neuronal glucose consumption ${ }^{18}$. Decrease of ${ }^{18} \mathrm{~F}$-FDG PET uptake is considered to be a direct index of synaptic dysfunction, which can result from a variety of neuropathological events, including but not limited to altered intracellular signaling cascades and mitochondria bioenergetics, impaired neurotransmitter release, and accumulation of neurotoxic protein species ${ }^{9,19}$. Of note, ${ }^{18} \mathrm{~F}-\mathrm{FDG}$ PET has been shown to be extremely sensitive to any perturbation in glucose metabolism, being able to capture neurodegeneration not only due to local pathological and biochemical alterations but also due to long-distance functional deafferentations ${ }^{9}$.

With regard to neurodegenerative diseases, a large and growing body of research has provided convincing and consistent evidence for highly specific patterns of ${ }^{18} \mathrm{~F}$-FDG PET hypometabolism in distinct dementia conditions ${ }^{9,20-26}$, even before manifest brain atrophy occurs ${ }^{27,28} \cdot{ }^{18} \mathrm{~F}$-FDG PET can provide support to differential diagnosis based on disease-specific hypometabolism patterns ${ }^{20,23,25,26,29,30}$. The ability of ${ }^{18} \mathrm{~F}$-FDG PET to capture disease-specific patterns led to the inclusion of ${ }^{18} \mathrm{~F}$-FDG PET hypometabolism as a supportive feature in the clinical/research diagnostic criteria of multiple dementia conditions ${ }^{1-6,8} .{ }^{18} \mathrm{~F}-\mathrm{FDG}$ PET is an accurate tool for early detection and estimation of increased risk for future dementia conversion $^{31}$ in the earliest clinical phases of disease, such as in subjects with mild cognitive impairment (MCI), as well as in preclinical cases (asymptomatic subjects at risk or asymptomatic carriers of pathogenetic mutations) $)^{25,32,33}$, providing highly relevant prognostic information for clinical use ${ }^{34}$. Crucially, the ability of ${ }^{18} \mathrm{~F}$-FDG PET to identify heterogeneous hypometabolism patterns in MCI allows clinicians to predict conversion not only to Alzheimer's disease (AD) dementia but also to non-AD dementia, avoiding multiple additional examinations and unnecessary delay in proper clinical management ${ }^{25,32}$. Given its high predictive value, ${ }^{18} \mathrm{~F}$-FDG PET will likely play a relevant role for patient inclusion in future clinical trials as an accurate tool to select patients at higher risk for short-term conversion to dementia ${ }^{34}$.

Notably, domain-specific cognitive deficits are known to be associated with network-specific functional alterations, which can be readily detected by ${ }^{18} \mathrm{~F}-\mathrm{FDG}$ PET ${ }^{35}$. The close relationship between ${ }^{18} \mathrm{~F}$-FDG PET and cognitive dysfunctions qualifies this tool as being relevant in the evaluation of treatment outcomes in patients with dementia ${ }^{36-41}$. Considering all of the above, we strongly recommend the introduction of ${ }^{18} \mathrm{~F}-\mathrm{FDG}$ PET in future clinical trials, also for the evaluation of therapy outcomes.

To date, a number of international workgroups and consortia have advocated for the relevance of ${ }^{18} \mathrm{~F}$-FDG PET in the diagnostic work-up of neurodegenerative diseases ${ }^{1-6,8,34}$. Nevertheless, a recent Cochrane review concluded that there is not enough evidence supporting the routine clinical use of ${ }^{18} \mathrm{~F}-\mathrm{FDG}$ PET in the diagnosis of dementia in the prodromal phase $\mathrm{e}^{42}$. This outcome was likely the consequence of the great methodological heterogeneity across ${ }^{18} \mathrm{~F}$-FDG PET literature, including study design, clinical cohorts, and, crucially, data analysis procedures, which are likely to considerably influence ${ }^{18}$ F-FDG PET accuracy, as remarked by a reply from the European Association of Nuclear Medicine ${ }^{43}$

The choice of appropriate and validated procedures remains a cardinal issue in ${ }^{18} \mathrm{~F}$-FDG PET data analysis. As for clinical diagnostic purposes, various quantitative and semi-quantitative approaches have been developed for single-subject analysis (such as statistical parametric mapping (SPM) $)^{44}$ and Neurostat $\left.{ }^{45-47}\right)^{12}$. SPM is one of the most diffuse methods to statistically analyze voxel-wise ${ }^{18} \mathrm{~F}$-FDG PET data ${ }^{34}$ and its accuracy has been validated in clinical research settings $\mathrm{s}^{25,26,30,33}$. A recently developed and validated single-subject SPM procedure takes advantage of an optimized spatial normalization, based on a custom ${ }^{18}$ F-FDG-PET dementiaspecific template, and of a high statistical accuracy of the resulting SPM t-maps, based on a large normal dataset for comparisons at the single-subject level ${ }^{30,48}$. This ${ }^{18} \mathrm{~F}$-FDG-PET SPM procedure allows the identification of disease-specific brain hypometabolism patterns in single cases, and in cross-validation studies for diagnostic accuracy it performs better than visual qualitative assessment of ${ }^{18}$ F-FDG-PET uptake images, clinical assessment of patients, cerebrospinal fluid biomarkers, and amyloid PET ${ }^{25,33}$. This method has been validated in clinical research settings both for differential dementia diagnosis ${ }^{23,25,26,30}$, including atypical parkinsonisms ${ }^{26}$, and for prognosis in prodromal cases ${ }^{25,30,32,33}$. We strongly support the implementation of this method not only in academic research 
but also in routine clinical settings. Other in vivo neuroimaging or cerebrospinal fluid biomarkers may also be added in the diagnostic work-up of cases with unclear ${ }^{18} \mathrm{~F}$-FDG-PET hypometabolism patterns, likely providing further support to dementia diagnosis.

In the last few years, neurodegenerative conditions have been progressively conceived as diseases of neural networks, which led to the development of multiple statistical multi-variate approaches able to capture their large-scale biological complexity ${ }^{49,50} \cdot{ }^{18} \mathrm{~F}-\mathrm{FDG}$ PET has been successfully used as a proxy to evaluate metabolic connectivity, assuming that regions whose metabolism is correlated are functionally interconnected ${ }^{51}$. Of note, distinct patterns of connectivity alterations are associated with different neurodegenerative conditions ${ }^{52}$. A reduced metabolic connectivity in the hippocampi and in the dorsolateral prefrontal cortex networks was reported in $\mathrm{AD}^{53}$, with an intermediate level of impairment found in $\mathrm{MCI}^{54}$. In contrast, a study on dementia with Lewy bodies (DLB) found altered metabolic connectivity in the occipital cortex, cerebellum, thalamus, and brain stem ${ }^{55}$. In Parkinson's disease (PD), an extensive decrease of connectivity in frontal regions, brain stem, and cerebellum was present ${ }^{56}$. Though compelling, the net majority of these findings are based on group-level analysis, and therefore the single-subject diagnostic value of metabolic connectivity approaches remains to be determined.

\section{Amyloid PET}

The first developed tracer for amyloid imaging was the ${ }^{18} \mathrm{~F}-\mathrm{FDDNP}$, eventually discarded for its affinity to both amyloid and tau ${ }^{57}$. Later, the "Pittsburgh compound B" $\left({ }^{11} \mathrm{C}-\mathrm{PiB}\right)$ was developed, despite the limitation of the carbon-11 short half-life, requiring an on-site cyclotron and limiting its use in clinical settings. Since 2012, ${ }^{18} \mathrm{~F}$-labelled amyloid radiotracers with longer half-life entered clinical and research evaluation in $\mathrm{AD}\left({ }^{18} \mathrm{~F}\right.$-florbetapir, ${ }^{18} \mathrm{~F}$-florbetaben, and ${ }^{18} \mathrm{~F}$-flutemetamol $)^{58}$. Since cortical retention for each ${ }^{18} \mathrm{~F}$ ligand is highly correlated among tracers ${ }^{59}$, amyloid-PET data obtained from different tracers may also be compared provided that standardized acquisition procedure ${ }^{60}$ and specific methods of analysis, such as the recently proposed Centiloid method ${ }^{61}$, are adopted. Standardization of acquisition procedures and data analysis will certainly improve the incorporation of amyloidPET biomarkers into the standard diagnostic criteria for $\mathrm{AD}^{3,5,7}$. Both ${ }^{11} \mathrm{C}$-PiB and ${ }^{18} \mathrm{~F}$-labelled amyloid-PET tracers bind with high affinity to fibrillar amyloid in neuritic plaques ${ }^{62-65}$. However, diffuse plaques with low fibrillarity and cerebral amyloid angiopathy (CAA) also contribute to part of tracer binding ${ }^{66}$.

The large amount of scientific evidence obtained by in vivo imaging of brain amyloid burden has challenged the primary role for amyloid in AD pathogenesis ${ }^{67,68}$. Still, appropriate use criteria for amyloid-PET imaging stress the high accuracy of amyloid $\mathrm{PET}$ in ruling out $\mathrm{AD}^{69}$ and in supporting $\mathrm{AD}$ dementia diagnosis, especially in three main clinical populations: (i) subjects with MCI, (ii) patients with suspected AD but atypical presentation or etiologically mixed presentation, and (iii) patients with earlyonset dementia ${ }^{70,71}$. Of note, in MCI, recent studies have shown that risk to convert to $\mathrm{AD}$ is greater in amyloid-positive subjects ${ }^{72}$ and that the time of conversion from MCI to AD dementia negatively correlates with the annual increase in amyloid deposition rate $^{73}$. However, since amyloid deposition rate increases rapidly in the prodromal phases of the disease ${ }^{74}$, in some subjects it might have already reached a plateau in the MCI stage ${ }^{22}$. For this reason, it has recently been suggested that amyloid rate might not be the best predictor of time to conversion from MCI to AD dementia as compared with neuronal injury biomarkers such as ${ }^{18} \mathrm{~F}-\mathrm{FDG}$ $\mathrm{PET}^{22}$. It should be taken into account that the characteristics of ${ }^{18} \mathrm{~F}$-FDG-PET hypometabolic patterns in MCI individuals can indicate the prognostic risk of progression to different dementia

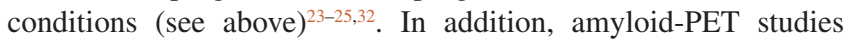
showed MCI patients presenting with wide variations in amyloid burden load ${ }^{75-77}$, sometimes showing an intermediate "gray area" burden, challenging attempts to classify it as either positive or negative ${ }^{78}$.

In patients with dementia, amyloid PET is recognized as a powerful tool to differentiate conditions characterized by a prominent amyloid deposition (that is, dementia due to AD) from those without, such as frontotemporal dementia (FTD) ${ }^{79}$. Recently, a comprehensive meta-analysis indicated that accuracy of amyloid PET in differential diagnosis of dementia might actually be circumscribed to relatively young demented patients since amyloid positivity dramatically increases with age in cognitively normal individuals (high prevalence after 70 years of age) and in non-AD dementia $^{80,81}$. Furthermore, amyloid PET cannot distinguish specific AD syndromes ${ }^{82,83}$ and other pathologies characterized by amyloidosis, such as DLB and CAA, and most studies show a non-specific pattern of amyloid burden diffusely distributed throughout the entire cortex across diseases ${ }^{84-86}$. Of note, in CAA, ${ }^{11} \mathrm{C}$-PiB was consistently shown to bind to cerebrovascular amyloid plaques, especially in the occipital cortex ${ }^{66,87}$. As a consequence, amyloid tracers should be regarded as a general marker of brain amyloidosis and not of specific AD amyloidosis ${ }^{12,66}$.

As for amyloid positivity in normal aging, it is currently debated whether cognitively normal subjects with a positive amyloid-PET scan represent prodromal AD cases who will eventually develop AD dementia or rather will remain stable $9,67,78,88$. Since variations in amyloid deposition rate in normal individuals are subtle (that is, $2-5 \%)^{89}$, a long follow-up might be necessary to observe development of dementia, and up to 19 years might be needed to reach the mean value of amyloid observed in $\mathrm{AD}^{90}$. However, the view that amyloid positivity equals AD dementia diagnosis has been challenged by the high prevalence of amyloid positivity in the elderly (about $44 \%$ in nonagenarians) despite normal cognitive function $^{80}$. Of note, the classification of amyloid-positive or -negative is dependent on the cutoff selected for positivity ${ }^{78}$, which varies according to the quantification method adopted for tracer binding estimation. In this regard, different quantification methods for amyloid PET have been proposed, including either compartmental model binding tools or reference tissue modelbased tools, and various regions of interests are suggested for the latter (for instance, ${ }^{91}$ ). A critical issue in amyloid-PET data analysis relates to the definition of the optimal reference region for semi-quantification. Most of the amyloid-PET studies tend to consider the cerebellum, as either a whole or gray matter only, as an optimal reference region, but the pons has been suggested as well ${ }^{92}$. Particular caution is needed in the case of longitudinal 
evaluation of amyloid-PET changes, where a direct standardized uptake value ratio (SUVR) semi-quantification could be sensitive to flow changes and produce biased results ${ }^{91}$. In longitudinal studies, the inclusion of a supratentorial white matter region should be considered for a robust reference ${ }^{93}$. It is generally accepted that compartmental models provide the most accurate results, and, for routine scans, a simplified reference tissue can be used ${ }^{94,95}$. Still, no specific guidelines for amyloid PET have been established yet ${ }^{91}$. Identification of an optimal normal versus abnormal cutoff with amyloid PET is also crucial in patient selection and inclusion in clinical trials.

Currently, amyloid PET imaging is a crucial requirement for inclusion/exclusion in clinical trials. The majority of clinical trials in $\mathrm{AD}$ have focused on amyloid therapies (for example, see references 96-98), also including serial amyloid-PET scans to evaluate decreases in cerebral amyloid burden ${ }^{97,98}$. An open question remains as to which amyloid-PET tracers are the most adequate to evaluate the efficacy of therapeutic interventions. Crucially, the adoption of amyloid-PET imaging for clinical trials has been criticized because currently available amyloid PET tracers measure fibrillary insoluble amyloid burden and are insensitive to toxic soluble amyloid oligomers ${ }^{99}$, which are much more clinically relevant ${ }^{100}$. From the methodological standpoint, clinical trials may suffer from the lack of appropriate quantification, usually limited to SUVR semi-quantification (for example, see references 96-98). Furthermore, the lack of a strong association between amyloid burden and measures of cognition and neurodegeneration ${ }^{68}$, as shown by several multi-tracer PET studies $^{82,83,101-104}$, suggests that clinical trials should include other pathological and topographical neurodegeneration biomarkers.

\section{Tau PET}

One of the most recent advances for in vivo PET imaging is the evaluation of cerebral tau burden ${ }^{105-108}$. Tau protein is physiologically associated with the stabilization, assembly, and functional integrity of microtubules, critical structures for cytoskeletal support and intracellular molecular transport ${ }^{109,110}$. Its hyperphosphorylation and accumulation are key pathogenic events in a number of neurodegenerative conditions (that is, tauopathies) and can potentially trigger remarkably different clinical phenotypes and disease courses ${ }^{109,111}$. Tau protein can present in six different isoforms, which are grouped on the basis of the number of microtubule-binding domain repeats (that is, three or four $(3 \mathrm{R} / 4 \mathrm{R}))^{110}$. In a normal brain, the ratio of $3 \mathrm{R} / 4 \mathrm{R}$ tau is $1: 1$, but it can change across the different pathologies, such as in the case of progressive supranuclear palsy (PSP) and corticobasal degeneration (CBD), which are 4R-dominant, or in the case of Pick's disease, which is $3 \mathrm{R}$-dominant ${ }^{108,109}$. When agglomerating, hyperphosphorylated tau can additionally assume different conformations, such as paired helical filaments (PHFs), straight filaments, and irregular filaments ${ }^{109}$. This biological complexity implies a considerably heterogeneous pathological picture which historically hampered the development of selective tau radioligands suitable for in vivo PET imaging ${ }^{106}$.

Notwithstanding tau biological complexity, the synthesis of some radioligands is now available and is rapidly entering into extensive research use and possibly for a potential validation in clinical practice ${ }^{108}$. To date, three broad groups of radioligands are under extensive evaluation: the ${ }^{18} \mathrm{~F}-\mathrm{THK} 5351,{ }^{18} \mathrm{~F}-\mathrm{THK} 5117$, or ${ }^{18} \mathrm{~F}-\mathrm{THK} 5105^{112-114}$; the ${ }^{18} \mathrm{~F}-\mathrm{T} 807$ (also known as ${ }^{18} \mathrm{~F}-\mathrm{AV} 1451$ or ${ }^{18} \mathrm{~F}$-Flortaucipir $)^{115}$; and the ${ }^{11} \mathrm{C}-\mathrm{PBB} 3{ }^{116}$.

The first tau PET imaging results in the AD spectrum have provided compelling evidence for a tight relationship between tau burden and synaptic dysfunction, gray matter atrophy, and cognitive deficits $^{117-120}$, confirming previous post-mortem evidence ${ }^{121,122}$. Early reports additionally suggested that tau PET was able to recapitulate the neuropathological Braak staging, suggesting that it could be a valuable tool for the in vivo staging of AD pathology progression $^{120,123}$. Multiple reports showed a cross-sectional association between worsening of cognitive impairment and increasing cortical tau-PET binding, from normal cognition to MCI and $\mathrm{AD}$ dementia stages ${ }^{117,118,120}$. Of note, the correspondence between tau accumulation, neurodegeneration, and clinical manifestations stands in stark contrast with amyloid-PET evidence, which is not associated with specific patterns of neurodegeneration or cognitive impairment (see "Amyloid PET" section above). The topographical specificity of tau-PET uptake distribution especially emerged for the $\mathrm{AD}$ variants, such as posterior cortical atrophy and the logopenic variant of primary progressive aphasia, which are known to be associated with phenotype-specific patterns of neurodegeneration and cognitive deficits ${ }^{124}$. These studies showed a consistent spatial correspondence between in vivo tau burden, neurodegeneration, and clinical syndromes, at group and singlesubject levels ${ }^{83,119,125-127}$.

The introduction of tau-PET techniques is reshaping the AD research field, allowing a more targeted evaluation of the original amyloid cascade hypothesis, which remains highly controversial (see "Amyloid PET" section above and ${ }^{67,128}$ ). Several studies specifically focused on the relationships between tau and amyloid accumulation in $\mathrm{AD}$ and in healthy aging ${ }^{119,120,129-133}$. The most consistent and compelling observation regards the variable patterns of tau deposition in subjects with or without a considerable cerebral amyloid burden ${ }^{108}$. Medial temporal lobe (MTL) tau accumulation has been associated with an age-related process independent from amyloid burden $^{133}$, whereas tau spreading outside the MTL is almost invariantly associated with an amyloid-positive status ${ }^{132-135}$.

While providing a wealth of evidence with critical implications for disease tracking and monitoring of $\mathrm{AD}$ interventions, the above-mentioned studies have also highlighted several areas of criticisms which are in need of further consideration ${ }^{136}$. Of note, the selectivity of the current tau-PET radioligands for non-AD tauopathies is not well understood. Previous autoradiographical studies on the most commonly adopted tau-PET compounds, such as the ${ }^{18} \mathrm{~F}-\mathrm{AV} 1451$, have shown high affinity for the AD tauopathy (that is, for intracellular neurofibrillary tangles composed of PHFs, with an equal 3R/4R tau ratio) ${ }^{137,138}$. The same, however, was not observed for the $4 \mathrm{R}$ tau aggregates typical of primary tauopathies, such as PSP or CBD, where post-mortem results are more heterogeneous and overall present less robust staining ${ }^{137-142}$. Another area of concern regards consistent non-specific tau-PET binding in subcortical structures, especially in the striatum and in the choroid plexus, in healthy controls, suggesting that the 
currently available tau tracers could present off-target binding, such as to neuromelanin ${ }^{137,138}$. The possibility that tau-PET ligands present non-specific binding is supported by a recent study showing that selegiline, a monoamine oxidase-B (MAO-B) inhibitor, significantly reduces brain ${ }^{18} \mathrm{~F}-\mathrm{THK} 5351$ uptake ${ }^{143}$. Additionally, it has been suggested that AV1451 could present non-specific binding to MAO-A as well ${ }^{144}$, even if there are opposite results ${ }^{145}$. Another issue in tau-PET quantification is represented by the time window adopted for SUVR semiquantification. As for ${ }^{18} \mathrm{~F}$-AV1451, the 80 - to 100-minute SUVR, commonly adopted in previous research studies ${ }^{136}$, might be not optimal given the evidence for a further $30 \%$ increase of SUVR values up to 180 minutes from injection ${ }^{146}$. The longer uptake time window of this tracer should be taken into account when such semi-quantifications are adopted ${ }^{146}$. Given these premises, tau-PET diagnostic value in $\mathrm{AD}$, and especially in non-AD tauopathies, is in need of further evaluation.

\section{Neuroinflammation PET}

In vivo imaging of neuroinflammation responses has recently gained particular interest in clinical neuroscience research ${ }^{147,148}$, and neuroinflammation has been recognized as a key player in the course of neurodegeneration ${ }^{149}$. The currently available PET molecular imaging techniques allow the measurement of neuroinflammation through imaging of both astrocytes and microglia activation ${ }^{147}$. Astrocytosis can be uniquely measured through PET and the ${ }^{11} \mathrm{C}$-deuterium-L-deprenyl ligand $\left({ }^{11} \mathrm{C}\right.$-DED), which is an irreversible inhibitor of the MAO-B enzyme, over-expressed during astrocyte activation ${ }^{150}$.

The great majority of research has otherwise focused on PET imaging of microglia activation, and many radioligands have been synthetized, the great majority of which target the overexpression of the $18-\mathrm{kDa}$ translocator protein (TSPO). TSPO is an outer mitochondrial membrane protein, expressed mostly by microglia and, to a lesser extent, by astrocytes ${ }^{151,152}$. Its levels in the central nervous system in healthy conditions are generally low, whereas their over-expression in the disease state has been well documented ${ }^{152}$.

Among the others, ${ }^{11} \mathrm{C}-(\mathrm{R})-\mathrm{PK} 11195$ is the first and prototypical TSPO radioligand ${ }^{153}$ and has been widely adopted in multiple neurodegenerative conditions ${ }^{147,154}$. A second generation of radioligands has been subsequently introduced, mainly to overcome some of the ${ }^{11} \mathrm{C}-(\mathrm{R})-\mathrm{PK} 11195$ limitations, such as limited availability of ${ }^{11} \mathrm{C}$ ligands in clinical settings and low signalto-noise ratio $^{155}$. These second-generation ligands come with both ${ }^{11} \mathrm{C}$ or ${ }^{18} \mathrm{~F}$ isotopes, such as ${ }^{11} \mathrm{C}$-PBR28 and ${ }^{18} \mathrm{~F}$-DPA714, and overall display higher binding affinities ${ }^{155}$. A few years ago, however, it was shown that a single-nucleotide polymorphism (that is, rs6971) in the TSPO gene can considerably influence the uptake of the second-generation tracers, making genetic testing mandatory ${ }^{156,157}$. While a third generation of fluorinated radioligands is currently under evaluation ${ }^{158}$, the ${ }^{11} \mathrm{C}$-(R)-PK11195 remains the best validated and diffusely adopted in human studies, not requiring TSPO genotype evaluation.
Of note, quantification of TSPO PET can be particularly challenging ${ }^{159}$ given the intrinsic characteristics of the TSPO protein $^{159}$. For instance, TSPO can be remarkably expressed in the endothelium, and it is heterogeneously distributed across the brain, hindering the definition of an anatomically defined reference region $^{159}$. To overcome the latter limit, several advanced clustering algorithms have been developed to iteratively select groups of voxels sharing specific time activity curves (that is, resembling temporal delivery of the tracer in gray matter without specific binding $)^{160-162}$. The complexity of TSPO-PET quantification and the use of radioligands with different properties, together with the characteristics of TSPO distribution, likely contributed to the pronounced heterogeneity of the reported findings in the literature. A representative example comes from TSPO-PET imaging of $\mathrm{AD}^{154,155,163}$. Previous studies have shown significant microglia activation in key AD signature regions, such as entorhinal and temporo-parietal areas, whereas some have reported negative results ${ }^{155}$. As for relation to disease phase, some studies described more significant microgliosis ${ }^{164}$ and astrogliosis ${ }^{165}$ in prodromal/ preclinical rather than $\mathrm{AD}$ dementia phases whereas others showed the opposite ${ }^{166}$. Of note, previous ${ }^{11} \mathrm{C}$-DED-PET studies have accordingly shown more significant astrocytosis in prodromal and preclinical genetic AD subjects when compared with subjects in later disease phases ${ }^{165,167}$. Diverging evidence also exists regarding the association between microglia activation and amyloid burden ${ }^{168-170}$. Several recent studies have provided novel evidence for longitudinal associations between neuroinflammation, neurodegeneration, and pathology accumulation in $\mathrm{AD}^{165,171,172}$. An increase of microglia activation in $\mathrm{AD}$ was longitudinally associated with amyloid accumulation and reductions of brain glucose metabolism ${ }^{171}$. Another recent study introduced a possible "two-peaks" model of microglia activation in $\mathrm{AD}^{172}$ with microgliosis first peaking at the prodromal MCI stage, afterwards declining approaching $\mathrm{AD}$ dementia transition, and then increasing again during the final disease stages ${ }^{172}$. As for ${ }^{11} \mathrm{C}$-DED PET, a recent longitudinal study on carriers of autosomal dominant AD mutations also indicated that the highest detected astrocyte activations were present at the asymptomatic stage, progressively decreasing approaching clinical onset ${ }^{165}$. Of note, amyloid accumulation followed an opposite trend ${ }^{165}$.

As for other neurodegenerative conditions, TSPO PET has been successfully applied in synucleinopathies, such as in DLB, PD, and PD with dementia ${ }^{173-175}$; in FTD ${ }^{176}$; in atypical parkinsonisms such as multiple system atrophy (MSA), CBD, and PSP ${ }^{177-179}$; and in prion diseases, such as Creutzfeldt-Jakob disease ${ }^{180}$.

Crucially, it remains to be understood whether this local immune response is thoroughly beneficial or rather can promote neurodegeneration ${ }^{149}$. This is particularly true in relation to microglia activation, which is a complex and dynamic process ${ }^{181}$. Understanding whether and how microglia is reacting within a disease course may provide important insights into disease pathogenesis and have remarkable implications for future clinical trials. PET imaging of neuroinflammation provides the unique chance of evaluating, in vivo, the reactivity of microglia cells, but 
also astrocytes by means of ${ }^{11} \mathrm{C}$-deprenyl PET, to either neuronal damage or pathology accumulation, with remarkable implications for research and possibly future clinical settings ${ }^{154,163}$.

Further validation of TSPO-PET imaging is needed to translate its application to clinical practice. Notwithstanding the broad efforts, the greatest challenge is still represented by the lack of a standardized methodology, which hampers the reproducibility and the biological interpretation of the findings. Additionally, the debate on the actual physiological role of the TSPO protein is yet to be solved ${ }^{182,183}$. One of the most remarkable future applications of neuroinflammation PET is the outcome evaluation of pharmacological interventions. Some studies have already used TSPO PET to monitor the anti-inflammatory or immunomodulatory therapies in $\mathrm{PD}^{184}$, MSA ${ }^{185}$, and multiple sclerosis ${ }^{186,187}$.

Several non-TSPO new targets to measure microglia activation with PET-based techniques, including but not limited to purinergic and cannabinoid receptors, are currently under evaluation ${ }^{188}$. The development of these new radioligands not only is linked to the attempt of overcoming TSPO intrinsic limits (see above) but also aims at the detection of specific microglial functional phenotypes $^{188}$. In neurodegenerative conditions, microglia can acquire very diverse functional phenotypes based upon several factors ${ }^{189}$; in this direction, the development of PET radioligands with particular affinity for specific microglial polarizations (for instance, homeostatic versus neurotoxic) would be of utmost importance. Preliminary data are available for PET imaging of the cannabinoid receptor type 2 (CB2R), which is over-expressed by microglial cells during activation and has been shown to promote neuroprotection ${ }^{190}$. The CB2R PET radioligand, ${ }^{11} \mathrm{C}-\mathrm{NE} 40$, has been recently used in patients with $\mathrm{AD}^{191}$. The development of PET tracers addressing phenotype-specific microglia activation will hopefully allow novel insights into how neuroinflammation responses could be contributing to neurodegeneration.

\section{Conclusions}

Recent studies have progressively highlighted how the same pathology can trigger very diverse functional phenotypes. Given the recent advances in neuroimaging techniques, it is likely that the multi-modal integration of pathological and functional biomarkers will be the key proxy to the most accurate identification of both underlying pathology and phenotypic syndrome, leading to the tailoring of the most appropriate care plan and prognosis. The increasing availability of PET in vivo pathology markers will likely favor the implementation of a spectrumbased research framework.

Although the clinical usefulness of amyloid PET is recognized, it is particularly recommended to specific clinical sub-populations, such as early and atypical clinical presentations. The novel tau tracers are promising, given their tight relationship with neurodegeneration, but the lack of affinity for different tau isoforms and the evidence for non-specific bindings shown by several of these radioligands call for the development of novel compounds overcoming these limitations. In this context, ${ }^{18} \mathrm{~F}-\mathrm{FDG}$ PET provides a well-validated key value to dementia diagnosis and prognosis and should be considered as one of the most valuable tools for monitoring neurodegenerative disease status and progression and also for selecting candidates for clinical trials and evaluating treatment response in both $\mathrm{AD}$ and non-AD pathologies.

\section{Abbreviations}

${ }^{11} \mathrm{C}$-DED, ${ }^{11} \mathrm{C}$-deuterium-L-deprenyl; ${ }^{11} \mathrm{C}-\mathrm{PiB}$, carbon-11 Pittsburgh compound $\mathrm{B} ;{ }^{18} \mathrm{~F}-\mathrm{FDG}$, fluorine-18 fluorodeoxyglucose; $\mathrm{AD}$, Alzheimer's disease; CAA, cerebral amyloid angiopathy; CB2R, cannabinoid receptor type 2; CBD, corticobasal degeneration; DLB, dementia with Lewy bodies; FTD, frontotemporal dementia; MAO, monoamine oxidase; MCI, mild cognitive impairment; MSA, multiple system atrophy; MTL, medial temporal lobe; PD, Parkinson's disease; PET, positron emission tomography; PHF, paired helical filament; PSP, progressive supranuclear palsy; SPM, statistical parametric mapping; SUVR, standardized uptake value ratio; TSPO, translocator protein.

\section{Author contributions}

All authors contributed to the preparation of the manuscript and agreed to the final content. DP conceived the study and revised the manuscript.

\section{Competing interests}

The authors declare that they have no competing interests.

\section{Grant information}

The author(s) declared that no grants were involved in supporting this work.
1. Albert MS, DeKosky ST, Dickson D, et al: The diagnosis of mild cognitive impairment due to Alzheimer's disease: recommendations from the National Institute on Aging-Alzheimer's Association workgroups on diagnostic guidelines for Alzheimer's disease. Alzheimers Dement. 2011; 7(3): 270-9. PubMed Abstract | Publisher Full Text | Free Full Text

2. $\mathrm{F}$ Gorno-Tempini ML, Hillis $\mathrm{AE}$, Weintraub $\mathrm{S}$, et al.: Classification of primary progressive aphasia and its variants. Neurology. 2011; 76(11): 1006-14. PubMed Abstract | Publisher Full Text | Free Full Text | F1000 Recommendation

3. McKhann GM, Knopman DS, Chertkow $\mathrm{H}$, et al:: The diagnosis of dementia due to Alzheimer's disease: recommendations from the National Institute on Aging-Alzheimer's Association workgroups on diagnostic guidelines for Alzheimer's disease. Alzheimers Dement. 2011; 7(3): 263-9. PubMed Abstract | Publisher Full Text | Free Full Text

4. F Rascovsky K, Hodges JR, Knopman D, et al:: Sensitivity of revised diagnostic criteria for the behavioural variant of frontotemporal dementia. Brain. 2011; 134(Pt 9): 2456-77.

PubMed Abstract | Publisher Full Text | Free Full Text | F1000 Recommendation 5. Sperling RA, Aisen PS, Beckett LA, et al:: Toward defining the preclinical stages 
of Alzheimer's disease: recommendations from the National Institute on Aging-Alzheimer's Association workgroups on diagnostic guidelines for Alzheimer's disease. Alzheimers Dement. 2011; 7(3): 280-92. PubMed Abstract | Publisher Full Text | Free Full Text

6. Armstrong MJ, Litvan I, Lang AE, et al:: Criteria for the diagnosis of corticobasa degeneration. Neurology. 2013; 80(5): 496-503.

PubMed Abstract | Publisher Full Text | Free Full Text

7. $\mathrm{F}$ Dubois B, Feldman $\mathrm{HH}$, Jacova $\mathrm{C}$, et al:: Advancing research diagnostic criteria for Alzheimer's disease: the IWG-2 criteria. Lancet Neurol. 2014; 13(6): $614-29$.

PubMed Abstract | Publisher Full Text | F1000 Recommendation

8. McKeith IG, Dickson DW, Lowe J, et al: Diagnosis and management of dementia with Lewy bodies: third report of the DLB Consortium. Neurology. 2005; 65(12): 1863-72.

PubMed Abstract | Publisher Full Text

9. Perani D: FDG-PET and amyloid-PET imaging: the diverging paths. Curr Opin Neurol. 2014; 27(4): 405-13.

PubMed Abstract | Publisher Full Text

10. Caroli A, Prestia A, Chen K, et al.: Summary metrics to assess Alzheimer disease-related hypometabolic pattern with ${ }^{18} \mathrm{~F}-\mathrm{FDG}$ PET: head-to-head comparison. J Nucl Med. 2012; 53(4): 592-600. PubMed Abstract | Publisher Full Text | Free Full Text

11. F Frisoni GB, Bocchetta M, Chételat G, et al.: Imaging markers for Alzheime disease: which vs how. Neurology. 2013; 81(5): 487-500.

PubMed Abstract | Publisher Full Text | Free Full Text | F1000 Recommendation

12. Perani $D$, Schillaci $O$, Padovani $A$, et al.: A survey of FDG- and amyloid-PET imaging in dementia and GRADE analysis. Biomed Res Int. 2014; 2014: 785039 PubMed Abstract | Publisher Full Text | Free Full Text

13. Frisoni GB, Perani D, Bastianello S, et al:: Biomarkers for the diagnosis of Alzheimer's disease in clinical practice: an Italian intersocietal roadmap. Neurobiol Aging. 2017; 52: 119-31.

PubMed Abstract | Publisher Full Text

14. Sokoloff L: Localization of functional activity in the central nervous system by measurement of glucose utilization with radioactive deoxyglucose. J Cereb

Blood Flow Metab. 1981; 1(1): 7-36.

PubMed Abstract | Publisher Full Text

15. Kadekaro M, Vance WH, Terrell ML, et al.: Effects of antidromic stimulation of the ventral root on glucose utilization in the ventral horn of the spinal cord in the rat. Proc Natl Acad Sci U S A. 1987; 84(15): 5492-5. PubMed Abstract | Publisher Full Text | Free Full Text

16. Pellerin L, Magistretti PJ: Glutamate uptake into astrocytes stimulates aerobic glycolysis: a mechanism coupling neuronal activity to glucose utilization. Proc Natl Acad Sci U S A. 1994; 91(22): 10625-9.

PubMed Abstract | Publisher Full Text | Free Full Text

17. F Lundgaard I, Li B, Xie L, et al.: Direct neuronal glucose uptake heralds activity-dependent increases in cerebral metabolism. Nat Commun. 2015; 6 : 6807.

PubMed Abstract | Publisher Full Text | Free Full Text | F1000 Recommendation

18. Zimmer ER, Parent MJ, Souza DG, et al:: $\left[{ }^{18} \mathrm{~F}\right] \mathrm{FDG}$ PET signal is driven by astroglial glutamate transport. Nat Neurosci. 2017; 20(3): 393-5. PubMed Abstract | Publisher Full Text | Free Full Text

19. Kato $T$, Inui $Y$, Nakamura A, et al.: Brain fluorodeoxyglucose (FDG) PET in dementia. Ageing Res Rev. 2016; 30: 73-84.

PubMed Abstract | Publisher Full Text

20. Teune LK, Bartels AL, de Jong BM, et al:: Typical cerebral metabolic patterns in neurodegenerative brain diseases. Mov Disord. 2010; 25(14): 2395-404. PubMed Abstract | Publisher Full Text

21. laccarino L, Crespi C, Della Rosa PA, et al.: The semantic variant of primary progressive aphasia: clinical and neuroimaging evidence in single subjects. PLoS One. 2015; 10(3): e0120197.

PubMed Abstract | Publisher Full Text | Free Full Text

22. Teipel S, Drzezga A, Grothe MJ, et al:: Multimodal imaging in Alzheimer's disease: validity and usefulness for early detection. Lancet Neurol. 2015; 14(10): 1037-53.

PubMed Abstract | Publisher Full Text

23. Cerami C, Dodich A, Greco L, et al: The Role of Single-Subject Brain Metabolic Patterns in the Early Differential Diagnosis of Primary Progressive Aphasias and in Prediction of Progression to Dementia. J Alzheimers Dis. 2017; 55(1): 183-97.

PubMed Abstract | Publisher Full Text | Free Full Text

24. Cerami C, Dodich A, Lettieri G, et al.: Different FDG-PET metabolic patterns a single-subject level in the behavioral variant of fronto-temporal dementia. Cortex. 2016; 83: 101-12.

PubMed Abstract | Publisher Full Text

25. Perani D, Cerami C, Caminiti SP, et al:: Cross-validation of biomarkers for the early differential diagnosis and prognosis of dementia in a clinical setting. Eu $J$ Nucl Med Mol Imaging. 2016; 43(3): 499-508.

PubMed Abstract | Publisher Full Text

26. Caminiti SP, Alongi $\mathrm{P}, \mathrm{Majno} \mathrm{L}$, et al: : Evaluation of an optimized $\left[{ }^{18} \mathrm{~F}\right]$ fluorodeoxy-glucose positron emission tomography voxel-wise method to early support differential diagnosis in atypical Parkinsonian disorders. Eur J Neurol. 2017; 24(5): 687-e26.

PubMed Abstract | Publisher Full Text

27. F Bateman RJ, Xiong C, Benzinger TL, et al:: Clinical and biomarker changes in dominantly inherited Alzheimer's disease. N Engl J Med. 2012; 367(9): 795-804.

PubMed Abstract | Publisher Full Text | Free Full Text | F1000 Recommendation

28. Chételat G, Desgranges B, Landeau B, et al.: Direct voxel-based comparison between grey matter hypometabolism and atrophy in Alzheimer's disease. Brain. 2008; 131(Pt 1): 60-71.

PubMed Abstract | Publisher Full Text

29. Cerami C, Crespi C, Della Rosa PA, et al:: Brain changes within the visuo-spatial attentional network in posterior cortical atrophy. J Alzheimers Dis. 2015; 43(2): 385-95.

PubMed Abstract | Publisher Full Text

30. Perani D, Della Rosa PA, Cerami C, et al:: Validation of an optimized SPM procedure for FDG-PET in dementia diagnosis in a clinical setting. Neuroimage Clin. 2014; 6: 445-54.

PubMed Abstract | Publisher Full Text | Free Full Text

31. Berti V, Polito C, Lombardi G, et al:: Rethinking on the concept of biomarkers in preclinical Alzheimer's disease. Neurol Sci. 2016; 37(5): 663-72.

PubMed Abstract | Publisher Full Text

32. Cerami C, Della Rosa PA, Magnani G, et al.: Brain metabolic maps in Mild Cognitive Impairment predict heterogeneity of progression to dementia. Neuroimage Clin. 2015; 7: 187-94.

PubMed Abstract | Publisher Full Text | Free Full Text

33. laccarino L, Chiotis K, Alongi $\mathrm{P}$, et al:: A Cross-Validation of FDG- and AmyloidPET Biomarkers in Mild Cognitive Impairment for the Risk Prediction to Dementia due to Alzheimer's Disease in a Clinical Setting. J Alzheimers Dis. 2017; 59(2): 603-14.

PubMed Abstract | Publisher Full Text

34. F Garibotto V, Herholz K, Boccardi M, et al.: Clinical validity of brain fluorodeoxyglucose positron emission tomography as a biomarker for Alzheimer's disease in the context of a structured 5-phase development framework. Neurobiol Aging. 2017; 52: 183-95.

PubMed Abstract | Publisher Full Text | F1000 Recommendation

35. Perani D: FDG PET and cognitive symptoms of dementia. Clin Trans/ Imaging. 2013; 1(4): 247-60.

Publisher Full Text

36. Potkin SG, Anand R, Fleming K, et al.: Brain metabolic and clinical effects of rivastigmine in Alzheimer's disease. Int J Neuropsychopharmacol. 2001; 4(3): 223-30

PubMed Abstract | Publisher Full Text

37. Smith GS, Kramer E, Ma Y, et al:: Cholinergic modulation of the cerebral metabolic response to citalopram in Alzheimer's disease. Brain. 2009; 132(Pt 2): 392-401.

PubMed Abstract | Publisher Full Text | Free Full Text

38. Satoh M, Ishikawa $\mathrm{H}$, Meguro $\mathrm{K}$, et al.: Improved visual hallucination by donepezil and occipital glucose metabolism in dementia with Lewy bodies: the Osaki-Tajiri project. Eur Neurol. 2010; 64(6): 337-44 PubMed Abstract | Publisher Full Text

39. Sultzer DL, Melrose RJ, Harwood DG, et al.: Effect of memantine treatment on regional cortical metabolism in Alzheimer's disease. Am J Geriatr Psychiatry. 2010; 18(7): 606-14

PubMed Abstract | Publisher Full Text

40. Keller C, Kadir A, Forsberg A, et al.: Long-term effects of galantamine treatment on brain functional activities as measured by PET in Alzheimer's disease patients. J Alzheimers Dis. 2011; 24(1): 109-23. PubMed Abstract | Publisher Full Text

41. Chow TW, Fam D, Graff-Guerrero A, et al.: Fluorodeoxyglucose positron emission tomography in semantic dementia after 6 months of memantine: an open-label pilot study. Int J Geriatr Psychiatry. 2013; 28(3): 319-25. PubMed Abstract | Publisher Full Text | Free Full Text

42. Smailagic N, Vacante M, Hyde C, et al:: ${ }^{18} \mathrm{~F}-\mathrm{FDG}$ PET for the early diagnosis of Alzheimer's disease dementia and other dementias in people with mild cognitive impairment (MCI). Cochrane Database Syst Rev. 2015; 1: CD010632. PubMed Abstract | Publisher Full Text

43. Morbelli S, Garibotto V, Van De Giessen E, et al.: A Cochrane review on brain ${ }^{18}$ F]FDG PET in dementia: limitations and future perspectives. Eur J Nucl Med Mol Imaging. 2015; 42(10): 1487-91. PubMed Abstract | Publisher Full Text

44. Friston $\mathrm{KJ}$, Holmes AP, Worsley KJ, et al:: Statistical parametric maps in functional imaging: A general linear approach. Hum Brain Mapp. 1994; 2(4): $189-210$.

Publisher Full Text

45. Minoshima S, Koeppe RA, Frey KA, et al:: Anatomic standardization: linear scaling and nonlinear warping of functional brain images. J Nucl Med. 1994 35(9): 1528-37.

PubMed Abstract

46. Minoshima S, Frey KA, Koeppe RA, et al:: A diagnostic approach in Alzheimer's disease using three-dimensional stereotactic surface projections of fluorine18-FDG PET. J Nucl Med. 1995; 36(7): 1238-48.

PubMed Abstract

47. Ishii K, Willoch F, Minoshima S, et al.: Statistical brain mapping of ${ }^{18}$ F-FDG PET in Alzheimer's disease: validation of anatomic standardization for atrophied brains. J Nucl Med. 2001; 42(4): 548-57. PubMed Abstract

48. Della Rosa PA, Cerami C, Gallivanone F, et al:: A standardized $\left[{ }^{18} \mathrm{~F}\right]-$ FDGPET template for spatial normalization in statistical parametric mapping of 
dementia. Neuroinformatics. 2014; 12(4): 575-93.

PubMed Abstract | Publisher Full Text

49. Lee DS, Kang H, Kim H, et al:: Metabolic connectivity by interregional correlation analysis using statistical parametric mapping (SPM) and FDG brain PET; methodological development and patterns of metabolic connectivity in adults. Eur J Nucl Med Mol Imaging. 2008; 35(9): 1681-91.

PubMed Abstract | Publisher Full Text

50. Huang S, Li J, Sun L, et al:: Learning brain connectivity of Alzheimer's disease by sparse inverse covariance estimation. Neuroimage. 2010; 50(3): 935-49. PubMed Abstract | Publisher Full Text | Free Full Text

51. Horwitz B, Duara R, Rapoport SI: Intercorrelations of glucose metabolic rates between brain regions: application to healthy males in a state of reduced sensory input. J Cereb Blood Flow Metab. 1984; 4(4): 484-99. PubMed Abstract | Publisher Full Text

52. Pievani M, Filippini N, van den Heuvel MP, et al:: Brain connectivity in neurodegenerative diseases--from phenotype to proteinopathy. Nat Rev Neurol. 2014; 10(11): 620-33.

PubMed Abstract | Publisher Full Text

53. Morbelli S, Drzezga A, Perneczky R, et al:: Resting metabolic connectivity in prodromal Alzheimer's disease. A European Alzheimer Disease Consortium (EADC) project. Neurobiol Aging. 2012; 33(11): 2533-50. PubMed Abstract | Publisher Full Text

54. Sanabria-Diaz G, Martínez-Montes E, Melie-Garcia L, et al:: Glucose metabolism during resting state reveals abnormal brain networks organization in the Alzheimer's disease and mild cognitive impairment. PLOS One. 2013; 8(7): e68860

PubMed Abstract | Publisher Full Text | Free Full Text

55. Caminiti SP, Tettamanti M, Sala A, et al:: Metabolic connectomics targeting brain pathology in dementia with Lewy bodies. J Cereb Blood Flow Metab. 2017; 37(4): 1311-25.

PubMed Abstract | Publisher Full Text | Free Full Text

56. Sala A, Caminiti SP, Presotto L, et al.: Altered brain metabolic connectivity at multiscale level in early Parkinson's disease. Sci Rep. 2017; 7(1): 4256. PubMed Abstract | Publisher Full Text | Free Full Text

57. Agdeppa ED, Kepe V, Liu J, et al:: Binding characteristics of radiofluorinated 6-dialkylamino-2-naphthylethylidene derivatives as positron emission tomography imaging probes for beta-amyloid plaques in Alzheimer's disease. J Neurosci. 2001; 21(24): RC189.

PubMed Abstract

58. Masdeu JC: Future Directions in Imaging Neurodegeneration. Curr Neurol Neurosci Rep. 2017; 17(1): 9. PubMed Abstract | Publisher Full Text

59. Landau SM, Thomas BA, Thurfjell L, et al.: Amyloid PET imaging in Alzheimer's disease: a comparison of three radiotracers. Eur J Nucl Med Mol Imaging. 2014 41(7): 1398-407.

PubMed Abstract | Publisher Full Text | Free Full Text

60. Minoshima S, Drzezga AE, Barthel H, et al:: SNMMI Procedure Standard/EANM Practice Guideline for Amyloid PET Imaging of the Brain 1.0. J Nucl Med. 2016; 57(8): 1316-22.

PubMed Abstract | Publisher Full Text

61. Klunk WE, Koeppe RA, Price JC, et al:: The Centiloid Project: standardizing quantitative amyloid plaque estimation by PET. Alzheimers Dement. 2015; 11(1): $1-15 . e 1-4$.

PubMed Abstract | Publisher Full Text | Free Full Text

62. Klunk WE, Engler H, Nordberg A, et al:: Imaging brain amyloid in Alzheimer's disease with Pittsburgh Compound-B. Ann Neurol. 2004; 55(3): 306-19. PubMed Abstract | Publisher Full Text

63. Choi SR, Schneider JA, Bennett DA, et al:: Correlation of amyloid PET ligand florbetapir $F \mathbf{1 8}$ binding with $A \beta$ aggregation and neuritic plaque deposition in postmortem brain tissue. Alzheimer Dis Assoc Disord. 2012; 26(1): 8-16. PubMed Abstract | Publisher Full Text | Free Full Text

64. Wolk DA, Grachev ID, Buckley $C$, et al:: Association between in vivo fluorine 18-labeled flutemetamol amyloid positron emission tomography imaging and in vivo cerebral cortical histopathology. Arch Neurol. 2011; 68(11): 1398-403. PubMed Abstract | Publisher Full Text | Free Full Text

65. Sabri O, Sabbagh MN, Seibyl J, et al:: Florbetaben PET imaging to detect amyloid beta plaques in Alzheimer's disease: phase 3 study. Alzheimers Dement. 2015; 11(8): 964-74.

PubMed Abstract | Publisher Full Text

66. Seo SW, Ayakta N, Grinberg LT, et al.: Regional correlations between $\left[{ }^{11} \mathrm{C}\right] \mathrm{PIB}$ PET and post-mortem burden of amyloid-beta pathology in a diverse neuropathological cohort. Neuroimage Clin. 2017; 13: 130-7. PubMed Abstract | Publisher Full Text | Free Full Text

67. F Herrup K: The case for rejecting the amyloid cascade hypothesis. Nat Neurosci. 2015; 18(6): 794-9.

PubMed Abstract | Publisher Full Text | F1000 Recommendation

68. Villemagne VL, Doré $\mathrm{V}$, Bourgeat $\mathrm{P}$, et al.: $\mathbf{A} \beta$-amyloid and Tau Imaging in Dementia. Semin Nucl Med. 2017; 47(1): 75-88.

PubMed Abstract | Publisher Full Text

69. Chételat G, Ossenkoppele R, Villemagne VL, et al:: Atrophy, hypometabolism and clinical trajectories in patients with amyloid-negative Alzheimer's disease. Brain. 2016; 139(Pt 9): 2528-39.

PubMed Abstract | Publisher Full Text
70. Johnson KA, Minoshima S, Bohnen NI, et al.: Update on appropriate use criteria for amyloid PET imaging: dementia experts, mild cognitive impairment, and education. Amyloid Imaging Task Force of the Alzheimer's Association and Society for Nuclear Medicine and Molecular Imaging. Alzheimers Dement. 2013; 9(4): e106-9. PubMed Abstract | Publisher Full Text

71. Guerra UP, Nobili FM, Padovani A, et al:: Recommendations from the Italian Interdisciplinary Working Group (AIMN, AIP, SINDEM) for the utilization of amyloid imaging in clinical practice. Neurol Sci. 2015; 36(6): 1075-81. PubMed Abstract | Publisher Full Text

72. Nordberg A, Carter SF, Rinne J, et al:: A European multicentre PET study of fibrillar amyloid in Alzheimer's disease. Eur J Nucl Med Mol Imaging. 2013; 40(1): 104-14

PubMed Abstract | Publisher Full Text | Free Full Text

73. Hatashita S, Wakebe D: Amyloid- $\beta$ Deposition and Long-Term Progression in Mild Cognitive Impairment due to Alzheimer's Disease Defined with Amyloid PET Imaging. J Alzheimers Dis. 2017; 57(3): 765-73.

PubMed Abstract | Publisher Full Text

74. Jack CR Jr, Wiste HJ, Lesnick TG, et al.: Brain $\beta$-amyloid load approaches a plateau. Neurology. 2013; 80(10): 890-6.

PubMed Abstract | Publisher Full Text | Free Full Text

75. Villemagne VL, Pike KE, Chételat G, et al:: Longitudinal assessment of $\mathbf{A} \beta$ and cognition in aging and Alzheimer disease. Ann Neurol. 2011; 69(1): 181-92. PubMed Abstract | Publisher Full Text | Free Full Text

76. F Petersen RC, Aisen P, Boeve BF, et al:: Mild cognitive impairment due to Alzheimer disease in the community. Ann Neurol. 2013; 74(2): 199-208. PubMed Abstract | Publisher Full Text | Free Full Text | F1000 Recommendation

77. Landau SM, Horng A, Fero A, et al:: Amyloid negativity in patients with clinically diagnosed Alzheimer disease and MCI. Neurology. 2016; 86(15): 1377-85. PubMed Abstract | Publisher Full Text | Free Full Text

78. Chételat $\mathrm{G}$, La Joie $\mathrm{R}$, Villain $\mathrm{N}$, et al:: Amyloid imaging in cognitively normal individuals, at-risk populations and preclinical Alzheimer's disease. Neuroimage Clin. 2013; 2: 356-65.

PubMed Abstract | Publisher Full Text | Free Full Text

79. Rabinovici GD, Rosen HJ, Alkalay A, et al.: Amyloid vs FDG-PET in the differential diagnosis of AD and FTLD. Neurology. 2011; 77(23): 2034-42. PubMed Abstract | Publisher Full Text | Free Full Text

80. F Jansen WJ, Ossenkoppele R, Knol DL, et al:: Prevalence of cerebral amyloid pathology in persons without dementia: a meta-analysis. JAMA. 2015; 313(19): 1924-38.

PubMed Abstract | Publisher Full Text | Free Full Text | F1000 Recommendation

81. F Ossenkoppele R, Jansen WJ, Rabinovici GD, et al:: Prevalence of amyloid PET positivity in dementia syndromes: a meta-analysis. JAMA. 2015; 313(19): 1939-49

PubMed Abstract | Publisher Full Text | Free Full Text | F1000 Recommendation

82. F Lehmann M, Ghosh PM, Madison C, et al:: Diverging patterns of amyloid deposition and hypometabolism in clinical variants of probable Alzheimer's disease. Brain. 2013; 136(Pt 3): 844-58.

PubMed Abstract | Publisher Full Text | Free Full Text | F1000 Recommendation

83. Dronse J, Fliessbach K, Bischof GN, et al:: In vivo Patterns of Tau Pathology, Amyloid- $\beta$ Burden, and Neuronal Dysfunction in Clinical Variants of Alzheimer's Disease. J Alzheimers Dis. 2017; 55(2): 465-71.

PubMed Abstract | Publisher Full Text

84. Maetzler W, Liepelt I, Reimold M, et al:: Cortical PIB binding in Lewy body disease is associated with Alzheimer-like characteristics. Neurobiol Dis. 2009 34(1): 107-12

PubMed Abstract | Publisher Full Text

85. Kantarci K, Lowe VJ, Boeve BF, et al:: AV-1451 tau and $\beta$-amyloid positron emission tomography imaging in dementia with Lewy bodies. Ann Neurol. 2017; 81(1): 58-67.

PubMed Abstract | Publisher Full Text | Free Full Text

86. Baron JC, Farid K, Dolan E, et al.: Diagnostic utility of amyloid PET in cerebra amyloid angiopathy-related symptomatic intracerebral hemorrhage. J Cereb Blood Flow Metab. 2014; 34(5): 753-8. PubMed Abstract | Publisher Full Text | Free Full Text

87. F Gurol ME, Dierksen G, Betensky R, et al:: Predicting sites of new hemorrhage with amyloid imaging in cerebral amyloid angiopathy. Neurology. 2012; 79(4): 320-6.

PubMed Abstract | Publisher Full Text | Free Full Text | F1000 Recommendation

88. Nordberg A: Dementia in 2014. Towards early diagnosis in Alzheimer disease. Nat Rev Neurol. 2015; 11(2): 69-70.

PubMed Abstract | Publisher Full Text

89. Roberts $B R$, Lind M, Wagen AZ, et al.: Biochemically-defined pools of amyloid- $\beta$ in sporadic Alzheimer's disease: correlation with amyloid PET. Brain. 2017; 140(5): 1486-1498.

PubMed Abstract | Publisher Full Text

90. $\mathrm{F}$ Villemagne VL, Burnham S, Bourgeat $\mathrm{P}$, et al: Amyloid $\beta$ deposition, neurodegeneration, and cognitive decline in sporadic Alzheimer's disease: a prospective cohort study. Lancet Neurol. 2013; 12(4): 357-67. PubMed Abstract | Publisher Full Text | F1000 Recommendation

91. van Berckel BN, Ossenkoppele R, Tolboom N, et al:: Longitudinal amyloid imaging using ${ }^{11} \mathrm{C}-\mathrm{PiB}$ : methodologic considerations. J Nucl Med. 2013; 54(9): 
$1570-6$

PubMed Abstract | Publisher Full Text

92. Edison $\mathrm{P}$, Hinz R, Ramlackhansingh $\mathrm{A}$, et al:: Can target-to-pons ratio be used as a reliable method for the analysis of $\left[{ }^{11} \mathrm{C}\right] \mathrm{PIB}$ brain scans? Neuroimage. 2012; 60(3): 1716-23.

PubMed Abstract | Publisher Full Text

93. Schwarz CG, Senjem ML, Gunter JL, et al: Optimizing PiB-PET SUVR change-over-time measurement by a large-scale analysis of longitudinal reliability, plausibility, separability, and correlation with MMSE. Neuroimage. 2017; 144(Pt A): 113-27.

PubMed Abstract | Publisher Full Text | Free Full Text

94. Heurling K, Leuzy A, Jonasson M, et al.: Quantitative positron emission tomography in brain research. Brain Res. 2017; 1670: 220-34. PubMed Abstract | Publisher Full Text

95. Lammertsma AA: Forward to the Past: The Case for Quantitative PET Imaging J Nucl Med. 2017; 58(7): 1019-24.

PubMed Abstract | Publisher Full Text

96. F Doody RS, Thomas RG, Farlow M, et al:: Phase $\mathbf{3}$ trials of solanezumab for mild-to-moderate Alzheimer's disease. N Engl J Med 2014; 370(4): 311-21. PubMed Abstract | Publisher Full Text | F1000 Recommendation

97. F Salloway S, Sperling R, Fox NC, et al.: Two phase 3 trials of bapineuzumab in mild-to-moderate Alzheimer's disease. N Engl J Med. 2014; 370(4): 322-33. PubMed Abstract | Publisher Full Text | Free Full Text | F1000 Recommendation

98. F Sevigny $\mathrm{J}$, Chiao $\mathrm{P}$, Bussière $\mathrm{T}$, et al.: The antibody aducanumab reduces $\mathbf{A} \boldsymbol{\beta}$ plaques in Alzheimer's disease. Nature. 2016; 537(7618): 50-6. PubMed Abstract | Publisher Full Text | F1000 Recommendation

99. Kayed R, Lasagna-Reeves CA: Molecular mechanisms of amyloid oligomers toxicity J Alzheimers Dis. 2013; 33 Suppl 1: S67-78.

PubMed Abstract | Publisher Full Text

100. Haass C, Selkoe DJ: Soluble protein oligomers in neurodegeneration: lessons from the Alzheimer's amyloid beta-peptide. Nat Rev Mol Cell Biol. 2007; 8(2): 101-12.

PubMed Abstract | Publisher Full Text

101. F Hedden $\mathrm{T}$, Oh $\mathrm{H}$, Younger AP, et al:: Meta-analysis of amyloid-cognition relations in cognitively normal older adults. Neurology. 2013; 80(14): 1341-8. PubMed Abstract | Publisher Full Text | Free Full Text | F1000 Recommendation

102. Jack CR Jr, Wiste HJ, Weigand SD, et al:: Amyloid-first and neurodegenerationfirst profiles characterize incident amyloid PET positivity. Neurology. 2013; 81(20): 1732-40.

PubMed Abstract | Publisher Full Text | Free Full Text

103. Ossenkoppele R, van der Flier WM, Verfaillie SC, et al.: Long-term effects of amyloid, hypometabolism, and atrophy on neuropsychological functions. Neurology. 2014; 82(20): 1768-75. PubMed Abstract | Publisher Full Text

104. Jagust WJ, Landau SM; Alzheimer's Disease Neuroimaging Initiative: Apolipoprotein $\mathrm{E}$, not fibrillar $\beta$-amyloid, reduces cerebral glucose metabolism in normal aging. $J$ Neurosci. 2012; 32(50): 18227-33. PubMed Abstract | Publisher Full Text | Free Full Text

105. Okamura N, Harada R, Furumoto S, et al.: Tau PET imaging in Alzheimer's disease. Curr Neurol Neurosci Rep. 2014; 14(11): 500 PubMed Abstract | Publisher Full Text

106. Villemagne VL, Okamura N: In vivo tau imaging: obstacles and progress. Alzheimers Dement. 2014; 10(3 Suppl): S254-64. PubMed Abstract | Publisher Full Text

107. Villemagne VL, Okamura N: Tau imaging in the study of ageing, Alzheimer's disease, and other neurodegenerative conditions. Curr Opin Neurobiol. 2016; 36: 43-51.

PubMed Abstract | Publisher Full Text

108. Okamura N, Harada R, Furukawa K, et al:: Advances in the development of tau PET radiotracers and their clinical applications. Ageing Res Rev. 2016; 30 $107-13$

PubMed Abstract | Publisher Full Text

109. Villemagne VL, Fodero-Tavoletti MT, Masters CL, et al:: Tau imaging: early progress and future directions. Lancet Neurol. 2015; 14(1): 114-24. PubMed Abstract | Publisher Full Text

110. Wang $\mathrm{Y}$, Mandelkow E: Tau in physiology and pathology. Nat Rev Neurosci. 2016; 17(1): 5-21. PubMed Abstract | Publisher Full Tex

111. Dickson DW, Kouri N, Murray ME, et al.: Neuropathology of frontotemporal lobar degeneration-tau (FTLD-tau). J Mol Neurosci. 2011; 45(3): 384-9. PubMed Abstract | Publisher Full Text | Free Full Text

112. F Okamura N, Furumoto S, Fodero-Tavoletti MT, et al.: Non-invasive assessment of Alzheimer's disease neurofibrillary pathology using ${ }^{18}$ F-THK5105 PET. Brain. 2014; 137(Pt 6): 1762-71. PubMed Abstract | Publisher Full Text | F1000 Recommendation

113. Harada R, Okamura N, Furumoto S, et al:: $\left[{ }^{18} \mathrm{~F}\right]$ THK-5117 PET for assessing neurofibrillary pathology in Alzheimer's disease. Eur J Nucl Med Mol Imaging. 2015; 42(7): 1052-61.

PubMed Abstract | Publisher Full Tex

114. Harada R, Okamura N, Furumoto S, et al:: ${ }^{18} \mathrm{~F}-\mathrm{TH}$ K5351: A Novel PET Radiotracer for Imaging Neurofibrillary Pathology in Alzheimer Disease. J Nucl Med. 2016;
57(2): 208-14

PubMed Abstract | Publisher Full Tex

115. Chien DT, Bahri S, Szardenings AK, et al:: Early clinical PET imaging results with the novel PHF-tau radioligand [F-18]-T807. J Alzheimers Dis. 2013; 34(2): 457-68.

PubMed Abstract | Publisher Full Text

116. $\mathrm{F}$ Maruyama M, Shimada $\mathrm{H}$, Suhara $\mathrm{T}$, et al:: Imaging of tau pathology in a tauopathy mouse model and in Alzheimer patients compared to norma controls. Neuron. 2013; 79(6): 1094-108.

PubMed Abstract | Publisher Full Text | Free Full Text | F1000 Recommendation

117. Cho H, Choi JY, Hwang MS, et al:: Tau PET in Alzheimer disease and mild cognitive impairment. Neurology. 2016; 87(4): 375-83. PubMed Abstract | Publisher Full Tex

118. F Johnson KA, Schultz A, Betensky RA, et al:: Tau positron emission tomographic imaging in aging and early Alzheimer disease. Ann Neurol. 2016; 79(1): 110-9.

PubMed Abstract | Publisher Full Text | Free Full Text | F1000 Recommendation

119. F Ossenkoppele R, Schonhaut DR, Schöll M, et al:: Tau PET patterns mirro clinical and neuroanatomical variability in Alzheimer's disease. Brain. 2016; 139(Pt 5): 1551-67.

PubMed Abstract | Publisher Full Text | Free Full Text | F1000 Recommendation

120. F Schöll M, Lockhart SN, Schonhaut DR, et al:: PET Imaging of Tau Deposition in the Aging Human Brain. Neuron. 2016; 89(5): 971-82.

PubMed Abstract | Publisher Full Text | Free Full Text | F1000 Recommendation

121. Nelson PT, Alafuzoff I, Bigio EH, et al:: Correlation of Alzheimer disease neuropathologic changes with cognitive status: a review of the literature. $J$ Neuropathol Exp Neurol. 2012; 71(5): 362-81. PubMed Abstract | Publisher Full Text | Free Full Tex

122. Murray ME, Lowe VJ, Graff-Radford NR, et al.: Clinicopathologic and ${ }^{11} \mathrm{C}$ Pittsburgh compound B implications of Thal amyloid phase across the Alzheimer's disease spectrum. Brain. 2015; 138(Pt 5): 1370-81. PubMed Abstract | Publisher Full Text | Free Full Text

123. Schwarz AJ, Yu P, Miller BB, et al.: Regional profiles of the candidate tau PET ligand ${ }^{18} \mathrm{~F}-\mathrm{AV}-1451$ recapitulate key features of Braak histopathological stages. Brain. 2016; 139(Pt 5): 1539-50.

PubMed Abstract | Publisher Full Text

124. Warren JD, Fletcher PD, Golden HL: The paradox of syndromic diversity in Alzheimer disease. Nat Rev Neurol. 2012; 8(8): 451-64. PubMed Abstract | Publisher Full Text

125. Ossenkoppele R, Schonhaut DR, Baker SL, et al.: Tau, amyloid, and hypometabolism in a patient with posterior cortical atrophy. Ann Neurol. 2015; 77(2): 338-42.

PubMed Abstract | Publisher Full Text | Free Full Text

126. Bischof GN, Jessen F, Fliessbach K, et al.: Impact of tau and amyloid burden on glucose metabolism in Alzheimer's disease. Ann Clin Transl Neurol. 2016; 3(12): 934-9.

PubMed Abstract | Publisher Full Text | Free Full Text

127. Xia C, Makaretz SJ, Caso C et al: Association of In Vivo [18F]AV-1451 Tau PET Imaging Results With Cortical Atrophy and Symptoms in Typical and Atypical Alzheimer Disease. JAMA Neurol. 2017; 74(4): 427-36. PubMed Abstract | Publisher Full Text | Free Full Text

128. Selkoe DJ, Hardy J: The amyloid hypothesis of Alzheimer's disease at 25 years. EMBO Mol Med. 2016; 8(6): 595-608. PubMed Abstract | Publisher Full Text | Free Full Text

129. Brier MR, Gordon $B$, Friedrichsen $\mathrm{K}$, et al:: Tau and A $\beta$ imaging, CSF measures, and cognition in Alzheimer's disease. Sci Transl Med. 2016; 8(338): 338ra66. PubMed Abstract | Publisher Full Text | Free Full Text

130. Chiotis K, Saint-Aubert L, Savitcheva I, et al.: Imaging in-vivo tau pathology in Alzheimer's disease with THK5317 PET in a multimodal paradigm. Eur J NuC Med Mol Imaging. 2016; 43(9): 1686-99.

PubMed Abstract | Publisher Full Text | Free Full Text

131. F Cho H, Choi JY, Hwang MS, et al.: In vivo cortical spreading pattern of tau and amyloid in the Alzheimer disease spectrum. Ann Neurol. 2016; 80(2): 247-58.

PubMed Abstract | Publisher Full Text | F1000 Recommendation

132. Lockhart SN, Schöll M, Baker SL, et al.: Amyloid and tau PET demonstrate region-specific associations in normal older people. Neuroimage. 2017; 150: $191-9$

PubMed Abstract | Publisher Full Text | Free Full Text

133. F Pontecorvo MJ, Devous MD Sr, Navitsky M, et al:: Relationships between flortaucipir PET tau binding and amyloid burden, clinical diagnosis, age and cognition. Brain. 2017; 140(3): 748-63.

PubMed Abstract | Publisher Full Text | Free Full Text | F1000 Recommendation

134. Hanseeuw BJ, Betensky RA, Schultz AP, et al.: Fluorodeoxyglucose metabolism associated with tau-amyloid interaction predicts memory decline. Ann Neurol. 2017; 81(4): 583-96.

PubMed Abstract | Publisher Full Text | Free Full Text

135. Vemuri $\mathrm{P}$, Lowe VJ, Knopman DS, et al:: Tau-PET uptake: Regional variation in average SUVR and impact of amyloid deposition. Alzheimers Dement (Amst). 2017: 6: 21-30.

PubMed Abstract | Publisher Full Text | Free Full Text 
136. Saint-Aubert L, Lemoine L, Chiotis K, et al:: Tau PET imaging: present and future directions. Mol Neurodegener. 2017; 12(1): 19 PubMed Abstract | Publisher Full Text | Free Full Text

137. F Marquié M, Normandin MD, Vanderburg $C R$, et al.: Validating novel tau positron emission tomography tracer [F-18]-AV-1451 (T807) on postmortem brain tissue. Ann Neurol. 2015; 78(5): 787-800. PubMed Abstract | Publisher Full Text | Free Full Text | F1000 Recommendation

138. Lowe VJ, Curran G, Fang P, et al:: An autoradiographic evaluation of AV-1451 Tau PET in dementia. Acta Neuropathol Commun. 2016; 4(1): 58. PubMed Abstract | Publisher Full Text | Free Full Text

139. Josephs KA, Whitwell JL, Tacik $P$, et al:: $\left[{ }^{18} \mathrm{~F}\right] \mathrm{AV}-1451$ tau-PET uptake does correlate with quantitatively measured $4 \mathrm{R}$-tau burden in autopsy-confirmed corticobasal degeneration. Acta Neuropathol. 2016; 132(6): 931-3. PubMed Abstract | Publisher Full Text | Free Full Text

140. Kikuchi A, Okamura N, Hasegawa T, et al:: In vivo visualization of tau deposits in corticobasal syndrome by ${ }^{18}$ F-THK5351 PET. Neurology. 2016; 87(22): 2309-16. PubMed Abstract | Publisher Full Text | Free Full Text

141. Sander K, Lashley T, Gami $\mathrm{P}$, et al:: Characterization of tau positron emission tomography tracer $\left.{ }^{\left[{ }^{18}\right.} \mathrm{F}\right] \mathrm{AV}-1451$ binding to postmortem tissue in Alzheimer's disease, primary tauopathies, and other dementias. Alzheimers Dement. 2016; 12(11): 1116-24. PubMed Abstract | Publisher Full Text

142. Ishiki A, Harada R, Okamura N, et al:: Tau imaging with $\left[{ }^{18} \mathrm{~F}\right] \mathrm{THK}-5351$ in progressive supranuclear palsy. Eur J Neurol. 2017; 24(1): 130-6. PubMed Abstract | Publisher Full Text

143. F Ng KP, Pascoal TA, Mathotaarachchi S, et al:: Monoamine oxidase B inhibitor, selegiline, reduces ${ }^{18} \mathrm{~F}-\mathrm{THK} 5351$ uptake in the human brain. Alzheimers Res Ther. 2017; 9(1): 25. PubMed Abstract | Publisher Full Text | Free Full Text | F1000 Recommendation

144. Hostetler ED, Walji AM, Zeng Z, et al:: Preclinical Characterization of ${ }^{18}$ F-MK-6240, a Promising PET Tracer for In Vivo Quantification of Human Neurofibrillary Tangles. J Nucl Med. 2016; 57(10): 1599-606. PubMed Abstract | Publisher Full Text

145. Xia CF, Arteaga J, Chen G, et al:: $\left[{ }^{18} \mathrm{~F}\right] \mathrm{T} 807$, a novel tau positron emission tomography imaging agent for Alzheimer's disease. Alzheimers Dement. 2013; 9(6): $666-76$.

PubMed Abstract | Publisher Full Text

146. Barret O, Alagille D, Sanabria S, et al.: Kinetic Modeling of the Tau PET Tracer ${ }^{18} \mathrm{~F}-\mathrm{AV}-1451$ in Human Healthy Volunteers and Alzheimer Disease Subjects. J Nucl Med. 2017; 58(7): 1124-31. PubMed Abstract | Publisher Full Text

147. Jacobs AH, Tavitian B; INMiND consortium, Noninvasive molecular imaging of neuroinflammation. J Cereb Blood Flow Metab. 2012; 32(7): 1393-415. PubMed Abstract | Publisher Full Text | Free Full Text

148. F Heneka MT, Carson MJ, El Khoury J, et al:: Neuroinflammation in Alzheimer's disease. Lancet Neurol. 2015; 14(4): 388-405. PubMed Abstract | Publisher Full Text | F1000 Recommendation

149. Ransohoff RM: How neuroinflammation contributes to neurodegeneration. Science. 2016; 353(6301): 777-83. PubMed Abstract | Publisher Full Text

150. Fowler JS, Logan J, Volkow ND, et al.: Translational neuroimaging: positron emission tomography studies of monoamine oxidase. Mol Imaging Biol. 2005; 7(6): 377-87.

PubMed Abstract | Publisher Full Text

151. Venneti S, Lopresti BJ, Wiley CA: The peripheral benzodiazepine receptor (Translocator protein $18 \mathrm{kDa}$ ) in microglia: from pathology to imaging. Prog Neurobiol. 2006; 80(6): 308-22. PubMed Abstract | Publisher Full Text | Free Full Text

152. Liu GJ, Middleton RJ, Hatty CR, et al.: The $\mathbf{1 8}$ kDa translocator protein, microglia and neuroinflammation. Brain Pathol. 2014; 24(6): 631-53. PubMed Abstract | Publisher Full Text

153. Chauveau $\mathrm{F}$, Boutin $\mathrm{H}$, Van Camp N, et al: Nuclear imaging of neuroinflammation: a comprehensive review of $\left[{ }^{11} \mathrm{C}\right] \mathrm{PK} 11195$ challengers Eur J Nucl Med Mol Imaging. 2008; 35(12): 2304-19. PubMed Abstract | Publisher Full Text

154. Schain M, KreisI WC: Neuroinflammation in Neurodegenerative Disorders-a Review. Curr Neurol Neurosci Rep. 2017; 17(3): 25. PubMed Abstract | Publisher Full Text

155. Dupont AC, Largeau B, Santiago Ribeiro MJ, et al.: Translocator Protein-18 kDa (TSPO) Positron Emission Tomography (PET) Imaging and Its Clinical Impact in Neurodegenerative Diseases. Int J Mol Sci. 2017; 18(4): pii: E785. PubMed Abstract | Publisher Full Text | Free Full Text

156. Owen DR, Howell OW, Tang SP, et al:: Two binding sites for $\left[{ }^{3} \mathrm{H}\right] \mathrm{PBR} 28$ in human brain: implications for TSPO PET imaging of neuroinflammation. $J$ Cereb Blood Flow Metab. 2010; 30(9): 1608-18. PubMed Abstract | Publisher Full Text | Free Full Text

157. Owen DR, Yeo AJ, Gunn RN, et al:: An 18-kDa translocator protein (TSPO) polymorphism explains differences in binding affinity of the PET radioligand PBR28. J Cereb Blood Flow Metab. 2012; 32(1): 1-5. PubMed Abstract | Publisher Full Text | Free Full Text

158. Fan Z, Calsolaro V, Atkinson RA, et al.: Flutriciclamide ( $\left.{ }^{18} \mathrm{~F}-\mathrm{GE} 180\right)$ PET: First-in-Human PET Study of Novel Third-Generation In Vivo Marker of Human
Translocator Protein. J Nucl Med. 2016; 57(11): 1753-9.

PubMed Abstract | Publisher Full Text

159. F Turkheimer FE, Rizzo G, Bloomfield PS, et al:: The methodology of TSPO imaging with positron emission tomography. Biochem Soc Trans. 2015; 43(4): $586-92$

PubMed Abstract | Publisher Full Text | Free Full Text | F1000 Recommendation

160. Turkheimer FE, Edison $\mathrm{P}$, Pavese $\mathrm{N}$, et al:: Reference and target region modeling of $\left[{ }^{11} \mathrm{C}\right]-(R)-P K 11195$ brain studies. J Nucl Med. 2007; 48(1): 158-67. PubMed Abstract

161. Yaqub M, van Berckel BN, Schuitemaker A, et al.: Optimization of supervised cluster analysis for extracting reference tissue input curves in $(R)$ [11C]PK11195 brain PET studies. J Cereb Blood Flow Metab. 2012; 32(8): 1600-8. PubMed Abstract | Publisher Full Text | Free Full Text

162. Presotto $L$, laccarino $L$, Bettinardi $V$, et al: : An automated clustering algorithm for reference region extraction of brain ${ }^{11} \mathrm{C}$-PK11195 studies. In: 2015 IEEE Nuclear Science Symposium and Medical Imaging Conference (NSS/MIC). San Diego, CA, USA. 1-3. Publisher Full Text

163. Stefaniak J, O'Brien J: Imaging of neuroinflammation in dementia: a review. J Neurol Neurosurg Psychiatr. 2016; 87(1): 21-8. PubMed Abstract | Publisher Full Text

164. Hamelin L, Lagarde J, Dorothée G, et al.: Early and protective microglial activation in Alzheimer's disease: a prospective study using ${ }^{18} \mathrm{~F}$-DPA-714 PET imaging. Brain. 2016; 139(Pt 4): 1252-64. PubMed Abstract | Publisher Full Text

165. F Rodriguez-Vieitez E, Saint-Aubert L, Carter SF, et al.: Diverging longitudinal changes in astrocytosis and amyloid PET in autosomal dominant Alzheimer's disease. Brain. 2016; 139(Pt 3): 922-36.

PubMed Abstract | Publisher Full Text | Free Full Text | F1000 Recommendation

166. KreisI WC, Lyoo CH, Liow JC, et al:: ${ }^{11} \mathrm{C}$-PBR28 binding to translocator protein increases with progression of Alzheimer's disease. Neurobiol Aging. 2016; 44: 53-61.

PubMed Abstract | Publisher Full Text | Free Full Text

167. F Carter SF, Schöll M, Almkvist O, et al.: Evidence for astrocytosis in prodromal Alzheimer disease provided by ${ }^{11} \mathrm{C}$-deuterium-L-deprenyl: a multitracer PET paradigm combining ${ }^{11} \mathrm{C}$-Pittsburgh compound $\mathrm{B}$ and ${ }^{18} \mathrm{~F}$-FDG. J Nucl Med. 2012; 53(1): 37-46.

PubMed Abstract | Publisher Full Text | F1000 Recommendation

168. Edison $\mathrm{P}$, Archer HA, Gerhard A, et al:: Microglia, amyloid, and cognition in Alzheimer's disease: An [ $\left.{ }^{11} \mathrm{C}\right](\mathrm{R}) \mathrm{PK} 11195-\mathrm{PET}$ and $\left[{ }^{11} \mathrm{C}\right] \mathrm{PIB}-\mathrm{PET}$ study. Neurobiol Dis. 2008; 32(3): 412-9.

PubMed Abstract | Publisher Full Text

169. Wiley CA, Lopresti BJ, Venneti S, et al:: Carbon 11-labeled Pittsburgh Compound $B$ and carbon 11-labeled (R)-PK11195 positron emission tomographic imaging in Alzheimer disease. Arch Neurol. 2009; 66(1): 60-7. PubMed Abstract | Publisher Full Text | Free Full Text

170. F Yokokura M, Mori N, Yagi S, et al.: In vivo changes in microglial activation and amyloid deposits in brain regions with hypometabolism in Alzheimer's disease. Eur J Nucl Med Mol Imaging. 2011; 38(2): 343-51. PubMed Abstract | Publisher Full Text | F1000 Recommendation

171. Fan Z, Okello AA, Brooks DJ, et al.: Longitudinal influence of microglial activation and amyloid on neuronal function in Alzheimer's disease. Brain. 2015; 138(Pt 12): 3685-98 PubMed Abstract | Publisher Full Text

172. F Fan Z, Brooks DJ, Okello A, et al.: An early and late peak in microglial activation in Alzheimer's disease trajectory. Brain. 2017; 140(3): 792-803. activation in Alzheimer's disease trajectory. Brain. 2017; 140(3):
PubMed Abstract | Publisher Full Text | F1000 Recommendation

173. Gerhard A, Pavese N, Hotton G, et al:: In vivo imaging of microglial activation with $\left[{ }^{11} \mathrm{C}\right](\boldsymbol{R})-\mathrm{PK} 11195$ PET in idiopathic Parkinson's disease. Neurobiol Dis. 2006; 21(2): 404-12. PubMed Abstract | Publisher Full Text

174. Iannaccone $\mathrm{S}$, Cerami $\mathrm{C}$, Alessio $\mathrm{M}$, et al.: In vivo microglia activation in very early dementia with Lewy bodies, comparison with Parkinson's disease. Parkinsonism Relat Disord. 2013; 19(1): 47-52. PubMed Abstract | Publisher Full Text

175. Fan Z, Aman Y, Ahmed I, et al.: Influence of microglial activation on neuronal function in Alzheimer's and Parkinson's disease dementia. Alzheimers Dement. 2015; 11(6): 608-21.e7. PubMed Abstract | Publisher Full Text

176. Cagnin A, Rossor M, Sampson EL, et al.: In vivo detection of microglial activation in frontotemporal dementia. Ann Neurol. 2004; 56(6): 894-7. PubMed Abstract | Publisher Full Text

177. Gerhard A, Banati RB, Goerres GB, et al:: [11 C](R)-PK11195 PET imaging of microglial activation in multiple system atrophy. Neurology. 2003; 61(5): 686-9. PubMed Abstract | Publisher Full Text

178. Gerhard A, Watts J, Trender-Gerhard I, et al.: In vivo imaging of microglial activation with $\left[{ }^{11} \mathrm{C}\right](R)-\mathrm{PK} 11195$ PET in corticobasal degeneration. Mov Disord. 2004; 19(10): 1221-6. PubMed Abstract | Publisher Full Text

179. Gerhard A, Trender-Gerhard I, Turkheimer F, et al:: In vivo imaging of microglial activation with $\left[{ }^{11} \mathrm{C}\right](\mathrm{R})-\mathrm{PK} 11195$ PET in progressive supranuclear palsy. Mov 
Disord. 2006; 21(1): 89-93.

PubMed Abstract | Publisher Full Text

180. laccarino L, Moresco RM, Presotto L, et al: An In vivo ${ }^{11} \mathrm{C}-(\mathrm{R})-\mathrm{PK} 11195$ PET and In Vitro Pathology Study of Microglia Activation in Creutzfeldt-Jakob Disease. Mol Neurobiol. 2017; 1-13.

PubMed Abstract | Publisher Full Text

181. Hanisch UK, Kettenmann $\mathrm{H}$ : Microglia: active sensor and versatile effector cells in the normal and pathologic brain. Nat Neurosci. 2007; 10(11): 1387-94. PubMed Abstract | Publisher Full Text

182. Gut $P, Z$ weckstetter M, Banati RB: Lost in translocation: the functions of the 18-kD translocator protein. Trends Endocrinol Metab. 2015; 26(7): 349-56. PubMed Abstract | Publisher Full Text

183. Selvaraj $\mathrm{V}$, Stocco DM: The changing landscape in translocator protein (TSPO) function. Trends Endocrinol Metab. 2015; 26(7): 341-8. PubMed Abstract | Publisher Full Text

184. F Jucaite A, Svenningsson $P$, Rinne JO, et al:: Effect of the myeloperoxidase inhibitor AZD3241 on microglia: a PET study in Parkinson's disease. Brain. 2015; 138(Pt 9): 2687-700.

PubMed Abstract | Publisher Full Text | F1000 Recommendation

185. Dodel R, Spottke A, Gerhard A, et al:: Minocycline 1-year therapy in multiplesystem-atrophy: effect on clinical symptoms and $\left[{ }^{11} \mathrm{C}\right](R)$-PK11195 PET (MEMSA-trial). Mov Disord. 2010; 25(1): 97-107.

PubMed Abstract | Publisher Full Text
186. Ratchford JN, Endres CJ, Hammoud DA, et al.: Decreased microglial activation in MS patients treated with glatiramer acetate. J Neurol. 2012; 259(6): 1199-205. PubMed Abstract | Publisher Full Text | Free Full Text

187. F Sucksdorff M, Rissanen E, Tuisku J, et al.: Evaluation of the Effect of Fingolimod Treatment on Microglial Activation Using Serial PET Imaging in Multiple Sclerosis. J Nucl Med. 2017; 58(10): 1646-1651. PubMed Abstract | Publisher Full Text | F1000 Recommendation

188. Tronel C, Largeau B, Santiago Ribeiro MJ, et al.: Molecular Targets for PET Imaging of Activated Microglia: The Current Situation and Future Expectations. Int J Mol Sci. 2017; 18(4): pii: E802.

PubMed Abstract | Publisher Full Text | Free Full Text

189. Perry VH, Nicoll JA, Holmes C: Microglia in neurodegenerative disease. Nat Rev Neurol. 2010; 6(4): 193-201.

PubMed Abstract | Publisher Full Tex

190. Price DA, Martinez AA, Seillier A, et al:: WIN55,212-2, a cannabinoid receptor agonist, protects against nigrostriatal cell loss in the 1-methyl-4-phenyl1,2,3,6-tetrahydropyridine mouse model of Parkinson's disease. Eur J Neurosci. 2009; 29(11): 2177-86.

PubMed Abstract | Publisher Full Text | Free Full Text

191. F Ahmad R, Postnov A, Bormans G, et al.: Decreased in vivo availability of the cannabinoid type 2 receptor in Alzheimer's disease. Eur J Nucl Med Mol Imaging. 2016; 43(12): 2219-27.

PubMed Abstract | Publisher Full Text | F1000 Recommendation 


\section{Open Peer Review}

\section{Current Peer Review Status:}

\section{Editorial Note on the Review Process}

Faculty Reviews are review articles written by the prestigious Members of Faculty Opinions. The articles are commissioned and peer reviewed before publication to ensure that the final, published version is comprehensive and accessible. The reviewers who approved the final version are listed with their names and affiliations.

\section{The reviewers who approved this article are:}

\section{Version 1}

\section{Karl Herholz}

University of Manchester, Manchester, UK

Competing Interests: No competing interests were disclosed.

\section{Sabina Pappata} Institute of Biostructure and Bioimaging (IBB), Consiglio Nazionale delle Ricerche (CNR), Naples, Italy Competing Interests: No competing interests were disclosed.

\section{Adriaan Lammertsma}

VU University Medical Center, Amsterdam, The Netherlands

Competing Interests: No competing interests were disclosed.

The benefits of publishing with F1000Research:

- Your article is published within days, with no editorial bias

- You can publish traditional articles, null/negative results, case reports, data notes and more

- The peer review process is transparent and collaborative

- Your article is indexed in PubMed after passing peer review

- Dedicated customer support at every stage

For pre-submission enquiries, contact research@f1000.com 